\title{
A historical-discursive analytical method for studying the formulation of public diplomacy institutions
}

\author{
Zhao Alexandre Huang $^{1}$ D
}

Revised: 29 September 2021 / Accepted: 18 October 2021 / Published online: 27 October 2021

(c) The Author(s), under exclusive licence to Springer Nature Limited 2021

\begin{abstract}
The aim of this study was to present a method of interpretative sociology for studying the formation and development of national public diplomacy institutions. Our goal was to apply cognitive analysis to public policy and to use a historicaldiscursive method to interpret the institutionalization of public diplomacy by a government. For us, cognitive analysis of public policy coordinates new perspectives and methods, especially the fruits of historical and discursive institutionalism, both to identify the cognitive and normative frames of policy formulation and to outline the dynamic relationships among institutions and political actors. By conducting an illustrative case study of China's public diplomacy institutionalization, we demonstrated the potential of historical-discursive analysis to shed light on public diplomacy institutional change and various social and rhetorical phenomena related to Beijing's efforts to rationalize and legitimize its foreign policy.
\end{abstract}

Keywords Public diplomacy $\cdot$ Cognitive analysis of public policy $\cdot$ Historical-discursive method $\cdot$ Interpretative sociology methodology $\cdot$ China

\section{Introduction}

Traditionally defined, public diplomacy is a set of direct communication dynamics in which an international actor mediates and implements its foreign policies toward foreign publics and manages international public opinion (Cull 2019; Golan et al. 2019). As a collection of methods and tools for wielding a nation-state's soft power, public diplomacy has received extensive interdisciplinary analysis (Gilboa 2008). From communication studies to political science, from marketing to public relations, from conflict management to rhetoric analysis, scholars have investigated various public diplomacy instruments, including advocacy, international broadcasting and journalism, cultural influence, relationship management, agenda setting, agenda building, and network interactions, to identify and explain the strategies and tactics of international communication and the power relations that govern it. However, the interdisciplinary nature of public diplomacy research "sometimes overshadows the

Zhao Alexandre Huang

zhao.huang@parisnanterre.fr

1 UFR Langues et Cultures Étrangères - Laboratory DICEN-IDF, Université Paris Nanterre, 200 avenue de la République, 92001 Nanterre Cedex, France connection between public diplomacy and foreign policy" (Ayhan 2018, p. 539).

As Sevin (2017) argued, even though public diplomacy contains "the label of diplomacy," scholars have paid limited attention to public diplomacy practice in diplomatic studies, especially in policy studies about international relations (26). Indeed, public diplomacy is a supplement to and expansion of traditional diplomatic behaviors. Framed and orientated by foreign policy, public diplomacy promotes the national interests of a state on the global stage (Tago 2017). Therefore, applying public policy analysis to public diplomacy can clarify the background, decision making, and motivations of foreign policy and public diplomacy institutions, demonstrating how policy actors can keep "(re)constructing visions of the world that allow them to (re)situate themselves in the world" (Hall 2015, p. 246).

The aim of this study was to present a method of interpretative sociology for analyzing the formation and development of national public diplomacy institutions. Our goal was to apply cognitive analysis to public policy and, more precisely, to use a historical-discursive analytical method to decipher the institutionalization of public diplomacy by a government. First, we discuss the conceptualization of cognitive analysis of public policy. Second, we clarify the specific methods of this cognitive analysis in the context 
of democracy. Finally, we use cognitive analysis of public policy to explore the potential of the historical-discursive analytical method as a tool for understanding public diplomacy institutions in China's autocratic regime.

\section{Cognitive analysis of public policy: decision making and positioning}

Defined as a "research construct" (Muller 2018, para. 34), public policy is "a government action plan in a sector of society or a geographic space" (Mény and Thoenig 1989, p. 130). Public diplomacy strategy, an integral part of foreign policy, regulates the global communication framework and manages international relations to defend and promote national interests (Merle 1984). In other words, foreign policy and domestic public policy are inseparable. On the one hand, the positioning of domestic policy could stem from a direct or indirect influence on foreign policy formulation; on the other hand, foreign policy "often integrates in the domestic political decisions process" (Braillard and Djalili 2016, p. 57).

Described as a "French touch in policy analysis" (Hall 2015, p. 237), cognitive analysis of public policy (l'analyse cognitive des politiques publiques), based on the constructivist approach to public policy making, underlines the particularity of political sociology as a component of political science that investigates how political processes relate to society (Berger and Luckmann 1967). Cognitive analysis examines "the actors, their behaviors, and their exchanges to better understand the consequences of public actions" (Duran 2010, p. 198). According to Muller (2018), cognitive analysis of public policy sheds light on "a process in which the society bestows its own understanding and manifestations of action on reality" (para. 5). In particular, the aim of cognitive analysis is to "classify and bring together analytical works that emphasize the weight of knowledge, ideas, representations, and/or social belief elements in the development of public policies" (Surel 2019, p. 87). Thus, cognitive analysis of public policy should reveal a "référentiel" (Muller 2014, p. 555) of the government's decision making, that is, formulation of socialization mechanisms that produce a coherent set of cognitive and normative elements that characterize public policy. In this way, the cognitive approach also has the potential to reveal "how [political] actors and private actors $[\ldots]$ concerned by the development and implementation of a policy position themselves" (Muller 2018, p. 50).

As a theorizing method, cognitive analysis of public policy considers the relations among social structures and political actors (Boussaguet et al. 2015). In other words, analyzing the cognitive frames of public policy underlines "the importance of the dynamics of the social construction of reality in the shaping of historically specific and socially legitimate frames and practices" (Surel 2000, p. 495). Thus, scholars tend to borrow new perspectives, especially historical and discursive institutionalism, to interpret the cognitive and normative frames of policy formulation while outlining the dynamics of the relations among institutions and political actors (Schmidt 2008; Hall 2015).

\section{Cognitive analysis and historical institutionalism}

From Plato's comparison of the way political systems shape behavior in Republic to Aristotle's discussion of the interdependence among institutional structure, political motives, and normative values in Politics, institutional theory has a long history. For political scientists, institutions are the "vessels in which politics [take] place," shaping human behavior and social action in domestic and international settings (Steinmo 2008, p. 120). Institutions are "rules" (Steinmo 2019, p. 367). They are "the rules of the game of a society or, more formally, the humanly devised constraints that shape human interactions" (North 1990, p. 3). This last definition highlights the restrictions that institutions impose on actors using an invisible cognitive and normative framework. Such a framework is the subject of "moral or cognitive models" of interpretation and practice for policy decision makers and actors (Hall and Taylor 1997, p. 473). These models promote the interrelationships and interdependence among actors and individuals from different political entities.

Crawford and Ostrom (1995) analyzed institutional change and formulated a "grammar of institutions" (582) with three inclusive approaches to exploring how they work (Baudassé et al. 2018). First, the institution promotes balance, building mutual understanding through "actor preferences and optimizing behavior" (Crawford and Ostrom 1995, p. 582). Second, the institution is a set of collective norms. This idea aligns with Lewis (2002), who understood convention as an array of rules formed by a group of individuals or a community based on a common understanding of convenience and discomfort. Third, the institution is a set of interactional rules that correspond to the argument by North (1990) that verbal and discursive constraints regulate collective social behaviors and actions. Therefore, institutions usually consist of rules, procedures, norms, ethical concepts, and behavioral constraints that people formulate and reformulate using discourse. As products of social actors, institutions are frameworks for interpreting the world (Muller 2005).

As an approach to understanding politics and social change, historical institutionalism centers around "actors in the national state, and its explanation for the birth and development of a modern centralized state [tends] to start at the top" (Sanders 2008, p. 45). From the perspective of structural-functionalism, scholars problematize and 
analyze the unexpected consequences and contingencies of strategic action, paying more attention to the historical context and cultural impact of institutional change in order to investigate and clarify the origin, evolution, and motivation of long-term collective choices and institutions. In the framework of historical institutionalism, institutions are not only variables of political effects (e.g., processes, rules, habits, and models anchored in a political system or in an organizational structure) (March and Olsen 1983) but also a "structuring variable through which battles of interests, ideas, and power take place" (Steinmo 2019, p. 384).

As argued by Pierson $(2000,2004)$, public policy scholars should not ignore issues related to social change. Historical institutionalists not only pay attention to the accumulation effects of historic, continuous, and small-scale reform (i.e., "positive feedback process") (Pierson 2000, p. 251) but also focus on the sequence of events, separating the "critical juncture" before institutional formulation from the positive feedback stage after formulation (252). These elements of path dependence are key factors in historical institutionalism. Because history traces the occurrence and context of certain events, it contains the legacy of institutional development. Research on the path dependence of institutional change addresses not only the initial path of emergence and the ongoing path of development but also the accidental factors often ignored by other institutional schools in order to identify the origins and sources of progressive public policy reform (Mabee 2011).

Moreover, according to Krasner (1984), institutional and historical development show the characteristics of "punctuated equilibrium" (240). In other words, changes in social and political structure over time lead to changes in institutional structure. For instance, the critical juncture after a crisis might constitute both a break in the evolution of an institution and a punctuated period of historical development. The political decisions made by an actor at this critical juncture are often the starting point for path dependence analysis, leading to greater understanding of the historical and social context of policy formation (Thelen 1999). Based on these ideas, Thelen and Steinmo (1992) refined the "four sources of institutional dynamism" to study institutional formation and change (16-17): (a) drastic changes in social-political context influence the appearance of potential institutions and redirect political outcomes; (b) social-economic changes and political tension lead new actors to reform the goals of existing institutions; (c) the formative influence of exogenous forces urges actors to alter the goals and strategies of the current institutional framework, leading to new objectives within older institutions; and (d) institutional strategy adjustment, especially at critical junctures, can lead to political struggles that generate institutional change.

\section{The "discursive turn" in cognitive analysis of public policy}

Applying historical institutionalism to cognitive analysis of public policy allows scholars to map the structural characteristics of the self-reinforcing paths of institutions; nevertheless, historical institutionalism cannot explain the critical junctures caused by structural change (Hall 2015). In other words, historical institutionalism conceives institutions as "entities that are external to agents, policies, structures, processes, values, norms, rituals, or meaning systems" (Kromidha and Córdoba-Pachón 2017, p. 17). This perception constrains the analysis of the role of various agents (whether political or non-political) when exploring the dynamics of institutional change. Thus, Schmidt $(2008,2015)$ suggested a discursive approach to comprehensively analyzing and understanding policy discourse, including ideas, values, and public policy norms. The aim of this approach is to expose, within the framework of institutions, the interactive processes of discourse and the substantive meaning of ideas.

According to Surel (2000), using a discursive approach when analyzing the cognitive and normative frames of public policy permits a comprehensive interpretation of political phenomena. On the one hand, the historical analysis of institutional patterns establishes a discursive framework. Within this framework, the discursive approach uses a "logic of communication" to "put ideas into their "meaning context"” (Schmidt 2008, p. 354). On the other hand, "politicians, officials, the spokesmen for social interests, and policy experts all operate within the terms of political discourse that are current in the nation at a given time, and the terms of political discourse generally have a specific configuration that lends representative legitimacy to some social interests" (Hall 1993, p. 289). Using discursive institutionalism, scholars can address institutional change and political discourse dynamically, highlighting the role of ideas in the formation and evolution of institutions (Sikkink 2012).

Inspired by Bourdieu's works on habitus (1987) and Searle's views on speech acts (1995), Schmidt (2008) defined discourse as the exchange of ideas in the construction of meaning; discourse is "a more versatile and overarching concept than ideas" $(2008,309)$ because "ideas are meaningful only by reference to a certain system of interpretation or discourse" (Panizza and Miorelli 2013, p. 304). Thus, the fundamental driving force behind institutional formation is ideas and the discourse they generate (Schmidt 2015). Based on this point of view, institutions are no longer structures but the patterns of thought within actors and their activity, giving rise to a common understanding and knowledge of reality. Discursive practices enable actors to estimate, question, and construct the world in certain ways, for "discourses set the parameters of what is sayable and indeed thinkable in a given social order" (Panizza and Miorelli 2013, p. 305). 
Therefore, discursive analysis can reveal the "full range of ways in which public policy operates, from the substantive content of ideas and values through to the interactive processes of agents in both the policy and political spheres" (Hall 2015, p. 246). The aim of discursive institutionalism is to transform discursive communication into institutional analysis, which explicitly or implicitly mediatizes, legitimizes, and rationalizes political ideas.

\section{A historical-discursive analytical method for cognitive analysis}

For Durand (2010), cognitive analysis of public policy focuses on apprehending a country through the actions and outcomes of the government. In other words, the aim of public policy analysis is to highlight the "the complexity of the relationship between political alternation and change" (Muller 2000, p. 190). In his Three Streams Theory, Kingdon (2013) mentioned that political agenda setting within the democratic framework often comes from the consensus formed after long-term discussion among various decision makers and stakeholders about "problem recognition, policy generation, and politics" (18).

Kingdon (2013) considered policy change based on the connection or combination of "three streams-problems, politics, and policies" (215). That is, policy change depends on the historical legitimacy of existing public policy and institutions and determines the direction of social evolution. Moreover, the three streams form a highly "organized anarchy" (84), for various policy makers, stakeholders, ideas, issues, solutions, strategies, and tactics join in the policymaking process like intertwined roots (Larkin 2012). This net of actors and structures makes the process too complex for simple observation. Understanding the formation of public policy within a democratic system requires seeing the historical path of institutional change as an orderly discursive structure in the context of social and political realities (Wodak and Ludwig 1999) and interpreting policy language and statements to reveal the diversity and heterogeneity of institutional discourse (Oger 2003).

Based on the lessons of historical and discursive institutionalism, we propose a historical-discursive analytical method for "recontextualizing" the political arguments, ideas, and concepts of a government (Wodak and Ludwig 1999, p. 13). Especially in the field of public diplomacy, this method can shed light on the evolution of institutional discourse through the work of decision makers (Maingueneau 2014) engaged in formulating and improving global communication strategies. The historical-discursive analytical method also requires attention to the interaction of actors who represent and express these rules from a relational perspective, for exchanging "the conventional contents of a concept for a sense of its meaning as a form of collective action enlarges its reach and our knowledge" (Becker 1998, p. 198). The basis of collective and formative action that shapes reality, knowledge has an interdependent and interactive relationship with power. Power derives from knowledge and both reproduces and (re)shapes knowledge according to particulars strategies, goals, or interests (Foucault 2006). Furthermore, discourses carry power because they convey the knowledge on which collective and individual consciousnesses depend (Wodak 2001).

Therefore, the historical-discursive analytical method is anthropo-sociological, permitting critical interpretation of the language used by political actors who represent collective political decision making. As Weber (1981) argued,

everything that is below the threshold of meaningfully interpretable behavior, oriented toward inner or outer "objects," is considered in just the same way as are the processes of nature, which are devoid of meaning-as condition or as object of orientation for the actor. [...] [T] he individual is [...] above this threshold and the only agent of meaningful behavior. [...] Concepts such as the "state," "association," "feudalism," and the like generally indicate for sociology categories of certain kinds of joint human action; it is therefore the task of sociology to reduce these concepts to "understandable" action, meaning, without exception, the action of the participating individuals. (158)

In other words, as a grounded and ethnographic methodology, historical-discursive analysis sheds light on the cohesion and dynamics between discourse and social reality (Berger and Luckmann 1967). It focuses on the historical and social background of the formation of institutions while preserving their endogenous meaning. According to Oger and Ollivier-Yaniv (2003), it includes "the activity, the experience, and the representations which are formulated by the social actors, particularly by means of language and speech" (130).

\section{Cognitive analysis of public policy application: China's institutionalization of public diplomacy}

Inspired by cognitive analysis of public policy, more and more political scholars have used historical and discursive methods to construct frameworks for explaining policy change (cf. Hall 2015; Mény and Thoenig 1989; Balme and Brouard 2005). This approach restores and permits interpretation of the traces of disputes partially erased during the formation of institutional discourse (e.g., public debates). It can also reveal the control of restraint systems implanted in the production of institutional discourse, which offers a 
normative frame for official statements (Oger 2003; Oger and Ollivier-Yaniv 2006). Scholars have used this methodology to demonstrate the advocacy strategies of various stakeholders in foreign policy formation and the public diplomacy decision-making process (cf. Charillon 2020; Charillon et al. 2018; Rouet and Radut-Gaghi 2018). However, scholars have rarely used it to examine the institutionalization of public diplomacy in an autocratic regime (e.g., China).

Numerous scholars have investigated China's current public diplomacy practice, discussing strategy formation (cf. Thussu 2016; Rawnsley 2009; Huang and Wang 2019; Zhao and Lei 2015), policies (cf. Zhao 2015, 2019; Wang 2012; d'Hooghe 2005), the meta-narratives of political leaders (cf. Wu et al. 2021), and the diverse aspects, representations, and communication instruments of China's public diplomacy through case studies (cf. Hartig 2016; Wu and Wang 2018; Huang and Wang 2020; Zhang et al. 2016). However, few have explored China's public diplomacy, from a historical perspective, within the institutional framework known as "major country diplomacy with Chinese characteristics." For scholars of China studies (cf. Carlson et al. 2010; Lam 2018), the party-state regime of the Communist Party of China (CPC) makes the conventional comparative approach to political science (e.g., investigating elections or social movements) difficult. Beijing's undemocratic authority, censorship of the so-called politically sensitive information, and manipulation of data for political purposes make the outside world question the accuracy of official reports. Moreover, China's political decision making lacks transparency. This reality slows down the proposal and development of effective methodologies and models for Chinese foreign policy studies.

\section{The evolution of China's foreign policy analysis}

To gain a comprehensive and subtle understanding of China's foreign policy making, China studies scholars first established the Pekingology method (White 1994, p. 16). Essentially Kremlinology with Chinese characteristics, this method involves a series of careful semio-discursive analysis vis-à-vis "esoteric communications" of Marxist-Leninist regimes (e.g., public statements of political leaders, images, and official documents) to describe the deep ideology and subtle meaning of the political speeches and policy strategies of ruling elites (Griffith 1970, p. 47). A product of CPC decision making, the content of official public statements made by Chinese leaders is highly institutionalized and normalized (Song 2016). Furthermore, most of the diplomacy that scholars examine in China's foreign policy research is institutional discourse rather than daily concrete action. Early on, Pekingology helped scholars collect and analyze political decisions and public speeches made public by state-owned media (Hillenbrand 2020).
As the central government began to assemble, edit, and publish internal documents, speeches by CPC leaders, and other archives, scholars gradually replaced Pekingology with more effective research methods. For instance, Zhou and Wu (2017) used historical institutionalism to investigate the historical roots and development of Beijing's external propaganda system; Bo (2017) and Wu et al. (2021) adopted critical discourse analysis to explain more comprehensively the root causes of political decisions and the reasons for institutional change in China. Using this method, they outlined the historical path of CPC doctrinal evolution and the intertextuality of policy and political rhetoric in the political speeches and narratives of Chinese leaders.

Indeed, the so-called "Chinese characteristics" of public diplomacy exist in the party-state's political perception of foreign policy. CPC theorists consider diplomacy a continuation of China's internal affairs (Zhao 2012). In other words, Beijing's public diplomacy needs to meet the domestic public policy goals of the CPC. Yu (2017) argued that "the strength or moderation of foreign strategy depends on how diplomacy serves internal affairs and consolidates CPC leadership" (para. 4). To explore the theory and institutions of China's public diplomacy, especially major-country diplomacy with Chinese characteristics, historical-discursive analysis (van Dijk 1997; Wodak 2001) can help scholars examine various developmental stages and strategic goals of Beijing's foreign policy and "understand and interpret practices and experiences" related to policy and institutional discourse formulation (Paillé and Mucchielli 2012, p. 13).

\section{Applying historical-discursive analysis to China's public diplomacy analysis: context and corpus}

Similar to concentric circles of restrictive goals and rules, institutional discourse is a set of expressions produced by "a singular or collective enunciator who occupies a legally educated position in the state apparatus, whether a civil servant or a political representative" (Oger and OllivierYaniv 2003, p. 127). In the particular party-state context of China, cognitive analysis of public policy depends on the instrument. Scholars who respect CPC doctrine tend to favor the cognitive analysis of Chinese foreign affairs (cf. Zhao 2015, 2012; Zhao and Lei 2015; Zhou and Wu 2017). Some have even inspired the theorization of public diplomacy or engaged in politics to become diplomats or "institutional writers" (Ollivier-Yaniv 2011, p. 58) who formulate language to fit China's foreign policy. Furthermore, the speeches of CPC political leaders are the cornerstone of the party-state's institutional formation. Indeed, individuals and expert groups at the CPC policy-making center formulate, review, and approve such speeches before political heads deliver them. On the one hand, these institutional discourses (i.e., speeches) are "coordinative" (Schmidt 2008, p. 310), 
reflecting the consensus of CPC policy makers. In finished form, they represent "Beijing's core values in the domestic and global governance systems, the collective decision of the central committee of the Party, and the general interest of Chinese citizens" (Guo 2017, p. 71). On the other hand, the speeches of China's political leaders are also "communicative" (Schmidt 2008, p. 310), serving the goals of CPC propaganda. Because of the ideological censorship in China's public sphere, the speeches of political leaders often contain elements of political propaganda to convey the policy ideas and institutional plans of the CPC (Arsène 2016). Moreover, these institutional discourses make their way into political textbooks, generalized by members of civil society through formal or informal means.

Based on this vision, Chinese scholars promote a "Chinese methodology" (Shi 2012, 8) for studying institutional discourse. Using "local, historical, and international environment factors" (Zhao 2013, p. 68), they investigate the "political discourses (the discourses of leaders), and academic discourses (the discourses of Chinese scholars)" that extend from the core ideas in speeches delivered by political leaders (Tian 2017, p. 31). In other words, the corpus of China's public diplomacy includes not only foreign policy texts and institutional regulations but also the relevant speeches, thoughts, and ideas of CPC leaders that constitute the theoretical system of Chinese socialism (Zhao 2005). Also worthy of inclusion are the academic discussions of Chinese scholars about related topics because "some Chinese researchers participated in the working groups of various ministries and the $\mathrm{CPC}$ in the name of think tank scholars to inspire the formulation of Chinese diplomatic doctrines and strategic planification" (Huang 2020, p. 161). Thus, historical-discursive analysis sheds light on the "institutional intertextuality" of political and academic discourse while also revealing institutional change related to China's public diplomacy.

The Chinese expression of inheritance and development (jicheng yu fazhan) is an appropriate way to describe changes in CPC doctrine. All innovations related to China's political institutions and political rhetoric derive from existing CPC dogma and systems. In other words, inheriting existing institutions and theoretical systems is a critical step in rationalizing and legitimizing new policies and systems (Song 2016). Therefore, to analyze the evolution of current public diplomacy policy in China, the corpus must include selected texts of CPC leaders published by the Central Institute of Party History and Literature ${ }^{1}$ from Mao Zedong to Xi

\footnotetext{
1 The Beijing government has published these contents on the Party's website "Theory China - Resource for Understanding China" in eight languages (www.theoryChina.org). This website is created and managed by the Central Institute of Party History and Literature. Scholars can visit it to access the CPC's political and historical documents.
}

Jinping. These documents contain speeches by CPC leaders about China's diplomatic institutions since Mao. In addition, corpus construction must also take into account the discourse of CPC politicians and scholars published on relevant websites of the Central Institute of Party History and Literature, especially Qiushi Theory.

\section{Outlining institutional formation paths and ideas of China's current public diplomacy}

Proposed by Chinese president Xi in 2014, the framework "major country diplomacy with Chinese characteristics" is the core of "Xi Jinping's Thoughts on Diplomacy" (Wang 2020, title). Chinese Premier Li (2016) defined this system as a set of international political communication efforts to "hold aloft the banner of peace, development, cooperation, and mutual benefit; to conduct [China's] diplomacy as a major country and safeguard its sovereignty, security, and developmental interests" (3). Chinese scholars have interpreted this political initiative as a sign that "China is confidently approaching the center of the world stage" (Xu 2017, para. 1). Although Beijing's public diplomacy remains an expression of "peace" and "common development" on the surface, from an institutional perspective, Xi Jinping's strategy calls for a "new type of great power relations" with other states, especially the United States and members of the European Union (Chang et al. 2016, para. 2). This rhetoric implies that Beijing is challenging existing international order to enhance its voice in current international relations (Yue 2008; Tan 2016; Zhou and Nie 2019).

\section{"Chinese Dream": the abandonment of previous public diplomacy institutions?}

The transfer of power in the CPC in 2012 marked the starting point for major changes in China's diplomatic institutions. When Xi Jinping announced the concept of "Chinese Dream," he signified a nationalist enthusiasm to promote the transformation of China's public diplomacy from passive to active (Zhao 2019; Roux and Xiao-Planes 2018).

China's conceptualization of public diplomacy first appeared in the 1980s. The goal was to improve Beijing's external propaganda (waixuan) using the "cultural and ideological penetration" strategies and tactics of the West ( $\mathrm{Zi}$ 1988, p. 13). The Tiananmen crisis in 1989 severely damaged the open international image that Beijing had established since the economic reform of 1978 (Taylor 2007). This crisis of confidence relates to how the suppression of the democratic movement on June 4, 1989 pushed Beijing to practice a low-key and prudent foreign policy doctrine. This doctrine, called taoguang yanghui, involved hiding the nation's capacity and biding its time for the right opportunity. The central government had to be not only discreet and 
patient but also strategic and wise in its international and geopolitical affairs. For then CPC leader Deng Xiaoping, taoguang yanghui urged the Chinese government to remain "calm and low-key" in international affairs and "work hard to do things right at home" (Deng 1994, p. 327). This pragmatic diplomatic system allowed China to gain the support of third-world states in the midst of a Western diplomatic blockade after the Tiananmen crisis and to create space for China's economic take-off in the 2000s (Taylor 2007; Cabestan 2015). Even though rumors of the "China threat" have accompanied China's economic development and expansion since the implantation of taoguang yanghui (cf. Roy 1996; Breslin 2013), Beijing has always adopted a circular and defensive diplomatic strategy in response to international criticism, continually emphasizing the term "peaceful rise" in its political rhetoric and institutions (Chen et al. 2009). For instance, former Chinese president Zemin (2002) introduced the term "soft power" to stress the importance of international communication in promoting China's peaceful development and friendly image. His successor, Hu Jintao, continued this strategy for eliminating international criticism by incorporating the terms "soft power" and "public diplomacy" into CPC doctrine (Huang and Wang 2019) and reinforcing this low-key diplomatic approach through his theory of harmonious coexistence (i.e., "constructing a harmonious world") to illustrate Beijing's efforts toward world peace, economic development, and international cooperation (Hu 2012, p. 1).

Nevertheless, Xi Jinping's proposal of the "Chinese Dream" broke with the low-key and patient doctrines that China's diplomatic system had long promoted, instead emphasizing "China's status as a global power" (Wu et al. 2021, p. 30). His aim was to reshape China's "nationalist political vision" (Roux and Xiao-Planes 2018, p. 305) and to rejuvenate "the Chinese nation" (Xi 2014a, p. 57). Thus, the polysemy of the term "Chinese Dream" is striking. It presents China as the subject of dreams and as the object of dreams, a China that not only citizens but also leaders and peoples around the world must dream into being, an idealized state (Huang and Arifon 2018).

\section{"Telling China Stories": the so-called "public-centric" practice and subtle rhetoric of CPC doctrine}

Promoting "Chinese Dream" requires effective instruments and strategies. Public diplomacy, in the eyes of Xi Jinping, is a series of communication activities related to the Party's "external publicity" and the goal of "telling the true story of our country and making our voice heard" (2014a, b, p. 188). With regard to public diplomacy, Xi Jinping embedded the concept "people-centered" in Beijing's renewal of international communication (Xin 2020, para. 6). The product was a public diplomacy with Chinese characteristics designed to "create new concepts, new categories, and new expressions that could be accepted by both China and foreign countries and publics" (Xi 2013,2) and to ensure that the preparation of all public diplomacy messages and narratives follow a "public-centric orientation" to shape target public perception (Xi 2018, para. 5).

From the perspective of historical and institutional discourse, this so-called public-centric rhetoric reflects Xi's inheritance and development of the "people's diplomacy" led by the central government under the framework of Maoism (Huang 2021). First, in Chinese politics and culture, the term public falls under the framework of public ownership (Huang and Hardy 2019). It does not represent social or private affairs but is a general term for "government affairs" (K. Zhao 2019, p. 170). For this reason, public diplomacy, according to Beijing, refers to a particular kind of government-led diplomacy or external propaganda practices in foreign civil society. Second, to gain international legitimacy for the CPC in the context of the Cold War, the Mao Zedong government engaged in a (para-)diplomatic campaign, namely people's diplomacy, based on the Party's doctrines of "making friends" and "doing business" (Zhou and Nie 2019, p. 62). Such people's diplomacy was nevertheless a foreign aid and external propaganda movement carried out and led by the CPC to strengthen relations between the Beijing government and third-world states in Asia, Africa, and Latin America. Indeed, influenced by ideas from Mao Zedong (1967), specifically "protracted war" (109) and "people's war" (168), China's so-called publiccentric people's diplomacy had the long-term functionalist goal of propaganda, namely "making [wars] by mobilizing the masses [and their thinking] and relying on them" (163) and "gaining access to foreign peoples, influencing them, and winning them over" (Zhou 1989, p. 97).

Xi Jinping summarized Mao Zedong's public-centric thoughts as "the enduring spirit" of CPC institutions (Xi 2014a, p. 49): "the mass line is the Party's lifeline and fundamental work principle" in the Party's propagandist works (27). China needs to "make friends and establish good relationships" with foreign counterparts to enhance "people-topeople exchanges" and "mutual understanding" about China's rise and national rejuvenation (Xi 2014b, para. 17) and to promote "mutual learning between Chinese civilization and other civilizations" (Xi 2019a, para. 8) under the framework of "community with a shared future" advocated by China (para. 16). The renewal of this public-centric approach allows Beijing to package the idea of "relationship management" within the framework of "major country diplomacy" and to promote China's initiatives for the construction of a new international order and discourse system (Ruan 2018, p. 13). However, such public-centric and community hypotheses derive from a kind of China-centrism that privileges the governing power of Beijing (McConnell and Woon 2021). In 
other words, the rhetoric of "public-centric" implies paternal management (Taylor 2004; Rawnsley 2020), the aim of which is to create a holistic communication and interaction network to orientate how domestic and foreign publics think about China through protracted, interactive, and daily communication and persuasion (Yao 2018; Huang and Wang 2021; Zaharna 2018).

Moreover, the institutional motivation for China's current public diplomacy stems from CPC efforts to enhance socialist cultural confidence. For Chinese political leaders, cultural confidence includes not only "creative evolution and development of fine traditional Chinese culture" but also "core socialist values" (Xi 2017, p. 20). Cultural confidence is an important part of CPC ideology and the strengthening of international public opinion management. For Xi (2014a), "ideological progress is one of its top priorities" (185), and enhancing socialist cultural confidence permits Beijing to "guide publics toward a more comprehensive and objective understanding of contemporary China" (188). To this end, China's public-centric public diplomacy storytelling aims to.

bring Chinese ideas, advocacy, and solutions to the international arena. [...] [China] must not only let the world know "China as represented by gastronomy" but also "academic China," "China in theory," "China in philosophy and social sciences," "China in development," "China in openness," and "China's contribution to human civilization." (Xi 2019a, b, Chapter 4, para. 2)

Finally, "telling China stories" is a subtle rhetoric for reconceptualizing and re-institutionalizing external CPC propaganda. According to the Chinese government, public diplomacy is a set of international communication activities "led by the central government" (Yang 2011, para. 2). CPC officials have argued that the essence of public diplomacy is an extension of CPC propaganda, with the aim of building China's reputation, legitimizing Chinese policies and initiatives, promoting Chinese modernization, and endorsing its peaceful rise (Zhao 2012; Zhao and Lei 2015). Under the framework "major country diplomacy with Chinese characteristics," public diplomacy activities follow the Party's political interests. That is, public diplomacy participates first and foremost in CPC governance of political and social life and censorship of domestic public opinion to secure "socialist" values and culture (Xi 2014a). Chinese public and private organizations and citizens supervised by the government then conduct public diplomacy activities, telling China stories to "enhance [China's] capability of international communication and spare no efforts in establishing a system for international speech to tell [...] and prove that China's path and system, both theoretical and social, are successful" (Xi 2014a, pp. 192-93). Through a series of long-term relational activities and storytelling, Beijing seeks to present a peaceful, friendly, and responsible image of the state to foreign publics. Doing so counterbalances perceptions of a dominant, conquering, and dangerous China regarding its comprehensive expansion in geopolitics (Tan 2016).

Therefore, from a historical-discursive perspective of institutional analysis, the diplomatic system and public diplomacy strategy of the "Chinese Dream" inherently relate to China's current domestic and foreign affairs. Beijing is redefining its status as an emerging power and active economy on the international stage through expressions such as "great renewal of the nation" and "community with a shared future for mankind" (Zhao 2019, 2015; Wu et al. 2021). The construction and dissemination of China's visions, ideas, and opinions internationally have become major objectives of Beijing's effort to construct and fight for discourse power (Zhou and Nie 2019). These aims require, on the one hand, that the socialist regime rapidly and continuously improve its international communication capacity to defend and improve its image as a successful socialist nation-state and, on the other hand, that China effectively deploy its soft power through a set of state-led communication actions in order to display China's political, diplomatic, economic, social, and cultural attractiveness as an emerging power.

\section{Conclusion}

From the perspective of cognitive analysis of public policy and interpretive sociology, we proposed a historical-discursive analytical method for examining the institutionalization and conceptualization of public diplomacy. This historical-discursive analysis method is a type of "ethnomethodology" for explaining the endogenous logic and meaning of a government's public diplomacy institutionalization and evolution (Oger and Ollivier-Yaniv 2003, p. 136). In a democratic context, public policy makers often express their intentions and strategies in visible ways (e.g., through "language games"; Pharo 1985, p. 127). Therefore, based on the precepts of historical institutionalism and discursive institutionalism, scholars can inspect institutional changes in public diplomacy and both perceive and interpret social and rhetorical phenomena related to a government's foreign policy implementation, mediatization, rationalization, and legitimization.

Based on an illustrative case study related to the institutional formation and developmental path of China's current public diplomacy in the framework "major country diplomacy with Chinese characteristics," we demonstrated the potential value of this method in the investigation of an autocratic regime's public diplomacy institutionalization. Although the concept of "public diplomacy" first appeared in CPC doctrine in 2012, Beijing's practices and regulations related to public diplomacy date back to the founding of the People's Republic of China. 
CPC has used several political terms (e.g., "people's diplomacy," "people to people diplomacy," "external propaganda," "united front," and "civil diplomacy") to describe and institutionalize public diplomacy practice in different periods. In future studies, scholars should consider using cognitive analysis of public policy to shed light on the institutional change and operational strategies of China's external propaganda before the integration of public diplomacy into CPC doctrine. The goals would be (a) to investigate the historical background of the formation of "Chinese characteristics" in public diplomacy and the foreign policy development and institutional roots of CPC and (b) to analyze the foundation of rhetorical production in Beijing's public diplomacy and the process by which China rationalized and mediatized various institutional discourses in the public sphere to establish legitimacy.

We also used cognitive analysis of public policy to understand China's current "wolf warrior" identity in public diplomacy and how that identity influences the definition, rules, strategies, and practice of public diplomacy with Chinese characteristics. Indeed, the COVID-19 pandemic, which began in late 2019, has filled the international political arena with significant uncertainty, and China has revealed to the world its provocative public diplomacy practices. Through Twitter and international broadcasting, Beijing's "wolf warrior" diplomats unanimously launched an aggressive communication war related to COVID-19 with the international community (Shepherd and Zhou 2020, title). Hua Chunying, a spokesperson for the Chinese Ministry of Foreign Affairs (MFA), argued that foreign media descriptions of this practice as "wolf warrior diplomacy" constituted "another version of the "China threat theory' and a discourse trap tailor-made for China" (Hua 2020, para. 39). For Beijing, such proactive public diplomacy practice contributes to the government's legitimate defense against provocations by Western states. The Chinese Vice-Minister of MFA also pointed out that "wolf warrior public diplomacy" is an important way for China to construct and enhance its global discourse power (guoji huayuquan), providing opportunities for Beijing to promote a new international order in the context of international political uncertainty (Le 2020). Thus, the true meaning and significance of "wolf warrior" public diplomacy needs more unpacking. The institutional roots and development of China's emerging foreign policy, as well as the relationship between "wolf warrior" public diplomacy and the nationalist idea of "Chinese Dream," are pathways for future study of public diplomacy with Chinese characteristics.

\section{References}

Arsène, Séverine. 2016. Global internet governance in Chinese academic literature: Rebalancing a hegemonic world order? China Perspectives 2: 25-35.
Ayhan, Kadir. 2018. Connecting public diplomacy and foreign policy. International Studies Review 20 (3): 539-540. https://doi.org/ 10.1093/isr/viy041.

Balme, Richard, and Sylvain Brouard. 2005. Les conséquences des choix politiques: Choix rationnel et action publique. Revue Française De Science Politique 55 (1): 33. https://doi.org/10.3917/ rfsp.551.0033.

Baudassé, Thierry, Rémi. Bazillier, and Isabelle Rabaud. 2018. Introduction: Quels liens entre migrations et institutions ? Mondes En Developpement 184 (4): 7-14.

Becker, Howard Saul. 1998. Tricks of the trade: How to think about your research while you're doing it. Chicago: University of Chicago Press.

Berger, Peter L., and Thomas Luckmann. 1967. The social construction of reality: A treatise in the sociology of knowledge. New York: Anchor.

Bo, Zhiyue. 2017. Factional politics in the Party-State apparatus. In Routledge Handbook of the Chinese Communist Party, edited by Willy Wo-Lap Lam, 217-36. New York: Routledge.

Bourdieu, P. 1987. Distinction-A social critique of the judgement of taste. Cambridge: Harvard University Press.

Boussaguet, Laurie, Sophie Jacquot, Pauline Ravinet, and Pierre Muller, eds. 2015. Une French touch dans l'analyse des politiques publiques. Paris: Presses de la Fondation nationale des sciences politiques.

Braillard, Philippe, and Mohammad-Reza Djalili. 2016. Chapitre III. La politique étrangère. Que sais-je? 55-71. Paris :PUF.

Breslin, Shaun. 2013. China and the global order: Signalling threat or friendship? International Affairs 89 (3): 615-634. https://doi.org/ 10.1111/1468-2346.12036.

Cabestan, Jean-Pierre. 2015. La politique internationale de la Chine: Entre intégration et volonté de puissance. Paris: Presses de Sciences Po.

Carlson, Allen, Mary E. Gallagher, Kenneth Lieberthal, and Melanie Manion, eds. 2010. Contemporary Chinese politics: New sources, methods, and field strategies. New York: Cambridge University Press.

Chang, Hong, Denghui Kang, and Bingjie Chen. 2016. zongshu: Xi Jinping de 'xinxing daguo guanxi' waijiao zhanlüe shi zheyang lianchengde [Summary: Xi Jinping's 'new type of great power relations' diplomatic strategy is refined like this]. People's Daily. http://world.people.com.cn/n1/2016/0213/c1002-28120530.html.

Charillon, Frédéric. 2020. Public Diplomacy à La Française. In Routledge handbook of public diplomacy, ed. Nancy Snow and Nicholas J. Cull, 264-272. New York: Routledge.

Charillon, Frédéric., Thierry Balzacq, and Frédéric. Ramel. 2018. La diplomatie de défense. In Manuel de diplomatie, ed. Thierry Balzacq, Frédéric. Charillon, and Frédéric. Ramel, 307-319. Paris: Presses de Sciences Po.

Chen, Gang, Jianfeng Chen, Xiaohe Cheng Xiaogang. Deng, Yong Deng, Joshua Kurlantzick, Zhongying Pang, Ignatius Wibowo, Lening Zhang, Yongjin Zhang, and Suisheng Zhao. 2009. Soft power: China's emerging strategy in international politics. Lanham: Lexington Books.

Crawford, Sue E. S., and Elinor Ostrom. 1995. A grammar of institutions. American Political Science Review 89 (3): 582-600. https://doi.org/10.2307/2082975.

Cull, Nicholas J. 2019. Public diplomacy: Foundations for global engagement in the digital age. Cambridge: Polity Press.

Deng, Xiaoping. 1994. Textes choisis, Deng Xiaoping. Tome 3. Pékin: Editions en langues étrangères.

Dijk, Teun A., and van. 1997. Discourse as social interaction. New York: SAGE Publications.

Duran, Patrice. 2010. Penser l'action publique. Paris: LGDJ Lextenso. Foucault, Michel. 2006. The will to knowledge. London: Penguin Books. 
Gilboa, Eytan. 2008. Searching for a theory of public diplomacy. The ANNALS of the American Academy of Political and Social Science 616 (1): 55-77. https://doi.org/10.1177/0002716207 312142.

Golan, Guy J., Ilan Manor, and Phillip Arceneaux. 2019. Mediated public diplomacy redefined: Foreign stakeholder engagement via paid, earned, shared, and owned media. American Behavioral Scientist 63 (12): 1665-1683. https://doi.org/10.1177/ 0002764219835279 .

Griffith, William E. 1970. On esoteric communications: Explication de texte. Studies in Comparative Communism 3 (1): 47-54.

Guo, Xuan. 2017. Discourse construction and global cognition of China's global governance initiatives. Shanghai: Shanghai International Studies University.

Hall, Peter A. 1993. Policy paradigms, social learning, and the state: The case of economic policymaking in britain. Comparative Politics 25 (3): 275-296. https://doi.org/10.2307/422246.

Hall, Peter A. 2015. Cognitive approaches: A French touch? In Une French Touch Dans l'analyse Des Politiques Publiques?, ed. Laurie Boussaguet, Sophie Jacquot, Pauline Ravinet, and Pierre Muller, 237-262. Paris: Presses de Sciences Po.

Hall, Peter A., and Rosemary C. R. Taylor. 1997. La science politique et les trois néo-institutionnalismes. Revue Française De Science Politique 47 (3): 469-496. https://doi.org/10.3406/ rfsp.1997.395192.

Hartig, Falk. 2016. Chinese public diplomacy: The rise of the Confucius Institute. Routledge New Diplomacy Studies. New York: Routledge.

Hillenbrand, Margaret. 2020. Selling the cryptosphere in China. $\mathrm{Cul}$ tural Studies 34 (4): 625-655. https://doi.org/10.1080/09502 386.2019.1671470.

Hooghe., Ingrid d'. 2005. Public diplomacy in the People's Republic of China. In The new public diplomacy: Soft power in international relations, ed. Jan Melissen, 88-105. London: Palgrave Macmillan.

Hu, Jintao. 2012. Firmly march on the path of socialism with Chinese Characteristics and strive to complete the building of a moderately prosperous society in all respects. Beijing. http:// language.chinadaily.com.cn/news/2012-11/19/content_15941 774_12.htm.

Hua, Chunying. 2020. Foreign ministry spokesperson Hua Chunying's regular press conference on December 10, 2020. Ministry of Foreign Affairs of the People's Republic of China. December 10. https://www.fmprc.gov.cn/mfa_eng/xwfw_665399/s2510_ 665401/t1839270.shtml.

Huang, Zhao Alexandre. 2020. Serving soft power and public diplomacy with Chinese characteristics: A communication analysis of the Confucius Institute at the University of Nairobi. Paris: COMUE Université Paris-Est.

Huang, Zhao Alexandre. 2021. The Confucius Institute and relationship management: uncertainty management of Chinese public diplomacy in Africa. In Public Diplomacy and the Politics of Uncertainty, edited by Pawel Surowiec and Ilan Manor, 197-223. Cham: Springer. https://doi.org/10.1007/978-3-030-54552-9_8.

Huang, Zhao Alexandre, and Olivier Arifon. 2018. La diplomatie publique chinoise sur Twitter: La fabrique d'une polyphonie harmonieuse. Hermès, La Revue, 81 (August): 45-53. https://doi.org/ 10.3917/herm.081.0045.

Huang, Zhao Alexandre, and Rui Wang. 2019. Building a network to 'tell China stories well': Chinese diplomatic communication strategies on Twitter. International Journal of Communication 13 (June): 2984-3007.

Huang, Zhao Alexandre, and Rui Wang. 2020. 'Panda Engagement' in China's digital public diplomacy. Asian Journal of Communication 30 (2): 118-140. https://doi.org/10.1080/01292986.2020. 1725075 .
Huang, Zhao Alexandre, and Rui Wang. 2021. Exploring China's digitalization of public diplomacy on Weibo and Twitter: A case study of the U.S.-China trade war. International Journal of Communication 15 (2021): 1912-1939.

Jiang, Zemin. 2002. Full text of Jiang Zemin's report at 16th party congress on Nov 8, 2002. Ministry of Foreign Affairs of the People's Republic of China. November 18. https://www.fmprc. gov.cn/mfa_eng/topics_665678/3698_665962/t18872.shtml.

Kingdon, John W. 2013. Agendas, alternatives, and public policies. Harlow: Pearson.

Krasner, Stephen D. 1984. Approaches to the state: Alternative conceptions and historical dynamics. Edited by Eric Nordlinger, Clifford Geertz, Stephen Skowronek, Charles Tilly, Raymond Grew, and Ellen Kay Trimberger. Comparative Politics 16 (2):223-46. https://doi.org/10.2307/421608.

Kromidha, Endrit, and José-Rodrigo. Córdoba-Pachón. 2017. Discursive institutionalism for reconciling change and stability in digital innovation public sector projects for development. Government Information Quarterly 34 (1): 16-25. https://doi. org/10.1016/j.giq.2016.11.004.

Lam, Willy Wo-Lap., ed. 2018. Routledge handbook of the Chinese communist party. New York: Routledge.

Larkin, Paul J. 2012. John Kingdon's 'Three Streams' theory and the antiterrorism and effective death penalty act of 1996. Journal of Law and Politics XXVIII 25: 25-50.

Le, Yucheng. 2020. waijiaobu fubuzhang le yucheng: dayiqing, dabianju huhuan datuanjie, dazuowei [Vice foreign minister Le Yucheng: The pandemic and the big changes call for great unity and great achievements]. Xinhua. December 5. http:// www.xinhuanet.com/2020-12/05/c_1126825981.htm.

Lewis, David. 2002. Convention: A philosophical study. Oxford: Wiley-Blackwell.

Li, Keqiang. 2016. Report on the work of the government (2016). http://www.catl.org.cn/2016-03/21/content_39842450_3.htm.

Mabee, Bryan. 2011. Historical institutionalism and foreign policy analysis: The origins of the national security council revisited: Historical institutionalism and foreign policy analysis. Foreign Policy Analysis 7 (1): 27-44. https://doi.org/10.1111/j.17438594.2010.00121.x.

Maingueneau, Dominique. 2014. Discours et analyse du discours: Une introduction. Paris: Armand Colin.

Mao, Tse-Tung. 1967. Selected works of Mao Tse-Tung., vol. 2. Beijing: Foreign Language Press.

March, James G., and Johan P. Olsen. 1983. The new institutionalism: Organizational factors in political life. American Political Science Review 78 (3): 734-749. https://doi.org/10.2307/ 1961840.

McConnell, Fiona, and Chih Yuan Woon. 2021. Mapping Chinese Diplomacy: Relational contradictions and spatial tensions. Geopolitics, August, 1-26. https://doi.org/10.1080/14650045. 2021.1966417.

Mény, Yves, and Jean-Claude. Thoenig. 1989. Politiques publiques. Paris: Presses universitaires de France.

Merle, Marcel. 1984. La politique étrangère. Paris: Presses universitaires de France.

Muller, Pierre. 2000. L'analyse cognitive des politiques publiques: Vers une sociologie politique de l'action publique. Revue Française De Science Politique 50 (2): 189-208. https://doi.org/10. 3406/rfsp.2000.395464.

Muller, Pierre. 2005. Esquisse d'une théorie du changement dans l'action publique: Structures, acteurs et cadres cognitifs. Revue Française De Science Politique 55 (1): 155. https://doi.org/10. 3917/rfsp.551.0155.

Muller, Pierre. 2014. Référentiel. Références : 555-62. Paris: Presses de Sciences Po 
Muller, Pierre. 2018. Chapitre III. Expliquer le changement : l'analyse cognitive des politiques publiques. Que sais-je?: 50-86. Paris: PUF

North, Douglass C. 1990. Institutions, institutional change, and economic performance. The Political Economy of Institutions and Decisions. Cambridge: Cambridge University Press.

Oger, Claire. 2003. Communication et contrôle de la parole: De la clôture à la mise en scène de l'institution millitaire. Quaderni 52 (1): 77-92. https://doi.org/10.3406/quad.2003.1582.

Oger, Claire, and Caroline Ollivier-Yaniv. 2003. Analyse du discours institutionnel et sociologie compréhensive : Vers une anthropologie des discours institutionnels. Mots 71 (March): 125-145. https://doi.org/10.4000/mots.8423.

Oger, Claire, and Caroline Ollivier-Yaniv. 2006. Conjurer Le Désordre Discursif. Les Procédés de « lissage » Dans La Fabrication Du Discours Institutionnel. Mots 81 (July): 63-77. https://doi.org/ 10.4000/mots.675.

Ollivier-Yaniv, Caroline. 2011. Les « petites phrases » et « éléments de langage ». Communication langages $\mathrm{N}^{\circ} 168$ (2): 57-68.

Paillé, Pierre, and Alex Mucchielli. 2012. Chapitre 1 - Choisir une approche d'analyse qualitative. Dictionnaire des méthodes qualitatives en sciences humaines et sociales: 13-32. Paris: Colin.

Panizza, Francisco, and Romina Miorelli. 2013. Taking discourse seriously: Discursive institutionalism and post-structuralist discourse theory. Political Studies 61 (2): 301-318. https://doi.org/ 10.1111/j.1467-9248.2012.00967.x.

Pharo, Patrick. 1985. Problèmes empiriques de la sociologie compréhensive. Revue Française De Sociologie 26 (1): 120-149. https://doi.org/10.2307/3321806.

Pierson, Paul. 2000. increasing returns, path dependence, and the study of politics. American Political Science Review 94 (2): 251-267. https://doi.org/10.2307/2586011.

Pierson, Paul. 2004. Politics in time: History, institutions, and social analysis. Princeton: Princeton University Press.

Rawnsley, Gary D. 2009. China talks back: Public diplomacy and soft power for the Chinese century. In Routledge International Handbooks, ed. Nancy Snow and Philip M. Taylor, 282-291. New York: Routledge.

Rawnsley, Gary D. 2020. Communicating confidence: China's public diplomacy. In Routledge Handbook of Public Diplomacy, edited by Nancy Snow and Nicholas J. Cull, 2nd ed., 284-300. New York: Routledge.

Rouet, Gilles, and Luciana Radut-Gaghi. 2018. Hermès, La Revue 2018/2: De la communication en diplomatie. Paris: CNRS Éditions.

Roux, Albert, and Xiaohong Xiao-Planes. 2018. Histoire de la République populaire de Chine: de Mao Zedong à Xi Jinping. Malakoff: Armand Colin.

Roy, Denny. 1996. The 'China threat' issue: Major arguments. Asian Survey 36 (8): 758-771. https://doi.org/10.2307/2645437.

Ruan, Zongze. 2018. Building a community with a shared future, helping China's strategic opportunity period. China International Studies, 1: 13-26.

Sanders, Elizabeth. 2008. Historical institutionalism. In The Oxford Handbook of Political Institutions, edited by R.A.W. Rhodes, Sarah A. Binder, and Bert A. Rockman, 39-55. Oxford: Oxford University Press. https://doi.org/10.1093/oxfordhb/9780199548 460.003.0003.

Schmidt, Vivien A. 2008. Discursive institutionalism: The explanatory power of ideas and discourse. Annual Review of Political Science 11 (1): 303-326. https://doi.org/10.1146/annurev.polis ci.11.060606.135342.

Schmidt, Vivien A. 2015. Discursive institutionalism: Understanding policy in context. In Handbook of critical policy studies, ed. Frank Fischer, Douglas Torgerson, Anna Durnová, and Michael Orsini, 171-189. Cheltenham: Edward Elgar Publishing.
Searle, John R. 1995. The construction of social reality. New York: Free Press.

Sevin, Efe. 2017. Public diplomacy and the implementation of foreign policy in the US, Sweden and Turkey. New York: Springer.

Shepherd, Christian, and Emma Zhou. 2020. The provocateur driving China's 'wolf warrior' pack. December 8. https://www.ft.com/ content/a1356c94-3c57-46b0-9d49-aa4b2e465287.

Shi, Xu. 2012. huayu yanjiu fangfa de zhongguo mpshi (A Chinese methodology for discourse studies). Journal of Guangdong University of Foreign Studies 23 (6): 5-8.

Sikkink, Kathryn. 2012. Ideas and institutions: Developmentalism in Brazil and Argentina. Ithaca: Cornell University Press.

Song, Haixiao. 2016. Pattern of decision-making of Chinese foreign policy. Beijing, China: Shishi chubanshe.

Steinmo, Sven. 2008. Historical institutionalism. In Approaches and methodologies in the social sciences: A pluralist perspective, edited by Donatella Della Porta and Michael Keating, 118-38. New York: Cambridge University Press.

Steinmo, Sven. 2019. Néo-institutionnalisme historique. In Dictionnaire des politiques publiques, ed. Laurie Boussaguet, Sophie Jacquot, and Pauline Ravinet, 382-390. Paris: Presses de Sciences Po.

Surel, Yves. 2000. The role of cognitive and normative frames in policy-making. Journal of European Public Policy 7 (4): 495-512. https://doi.org/10.1080/13501760050165334.

Surel, Yves. 2019. Approches cognitives. In Dictionnaire des politiques publiques, edited by Laurie Boussaguet, Sophie Jacquot, Pauline Ravinet, Peter A Hall, and Pierre Muller, 87-94. Paris: Presses de Sciences Po.

Tago, Atsushi. 2017. Public diplomacy and foreign policy. In Oxford Research Encyclopedia of Politics, by Atsushi Tago. Oxford: Oxford University Press. https://doi.org/10.1093/acrefore/ 9780190228637.013 .471$.

Tan, Youzhi. 2016. Construction strategy for Chinese public diplomacy from the perspective of international discourse power. Beijing: China social sciences press.

Taylor, Ian. 2004. The 'All-Weather Friend'? Sino-African Interaction in the Twenty-First Century. In Africa in international politics: External involvement on the continent, ed. Ian Taylor and Paul Williams, 83-101. London: Routledge.

Taylor, Ian. 2007. China and Africa: Engagement and compromise. 1st ed. Routledge. https://doi.org/10.4324/9780203968635.

Thelen, Kathleen. 1999. Historical institutionalism in comparative politics. Annual Review of Political Science 2: 369-404.

Thelen, Kathleen, and Sven Steinmo. 1992. Historical institutionalism in comparative politics. In Structuring politics: Historical institutionalism in comparative analysis, ed. Sven Steinmo, Kathleen Thelen, and Frank Longstreth, 1-32. Cambridge: Cambridge University Press.

Thussu, Daya. 2016. The scramble for Asian soft power in Africa. Les Enjeux De L'information Et De La Communication 2 (17): 225-237.

Tian, Yuanyuan. 2017. zhongguo tese shehui zhuyi huayu tixi yanjiu zongshu [A summary of the research on socialism discourse system with Chinese characteristics]. Journal of Social Sciences of Jiamusi University 35 (6): 30-33.

Wang, Yiwei. 2012. domestic constraints on the rise of Chinese public diplomacy. The Hague Journal of Diplomacy 7 (4): 459-472. https://doi.org/10.1163/1871191X-12341237.

Wang, Yi. 2020. Study and implement Xi Jinping thought on diplomacy conscientiously and break new ground in major-country diplomacy with Chinese characteristics. Ministry of Foreign Affairs of the People's Republic of China. July 20. https://www. fmprc.gov.cn/mfa_eng/zxxx_662805/t1799305.shtml. 
Weber, Max. 1981. Some categories of interpretive sociology. The Sociological Quarterly 22 (2): 151-180. https://doi.org/10. 1111/j.1533-8525.1981.tb00654.x.

White, Gordon. 1994. Riding the tiger: The politics of economic reform in post-Mao China. Basingstoke: Macmillan.

Wodak, Ruth. 2001. The discourse-historical approach. Methods of Critical Discourse Analysis 1: 63-94.

Wodak, Ruth, and Christoph Ludwig. 1999. Challenges in a changing world: Issues in critical discourse analysis. Vienna: Passagen.

Wu, Di., and Jian Jay Wang. 2018. Country image in public diplomacy: From messages to relationships. In Bridging disciplinary perspectives of country image reputation, brand, and identity, ed. Diana Ingenhoff, Candace White, Alexander Buhmann, and Spiro Kiousis, 244-262. New York: Routledge.

$\mathrm{Wu}$, Yan, Richard Thomas, and Yakun Yu. 2021. From external propaganda to mediated public diplomacy: The construction of the Chinese dream in president Xi Jinping's new year speeches. In Public diplomacy and the politics of uncertainty, edited by Pawel Surowiec and Ilan Manor, 29-55. Cham: Springer. https://doi. org/10.1007/978-3-030-54552-9_2.

Xi, Jinping. 2013. Xi Jinping: Ideological work is an extremely important task of the party. Xinhua, August 20. http://www.xinhuanet. com//politics/2013-08/20/c_117021464.htm.

Xi, Jinping. 2014a. Xi Jinping: The governance of China [E-book]. Beijing: Foreign Language Press.

$\mathrm{Xi}$, Jinping. 2014b. zai zhongguo guoji youhao dahui shang de jianghua [Speech at the China international friendship conference]. People's Daily. May 16. http://politics.people.com.cn/n/2014/0516/ c1024-25023611.html.

Xi, Jinping. 2017. Secure a decisive victory in building a moderately prosperous. Beijing: 19th National Congress of the Communist Party of China.

Xi, Jinping. 2018. Xi Jinping attended the national conference on propaganda and ideological work and delivered an important speech. The State Council - The People's Republic of China, September 29. http://www.gov.cn/xinwen/2018-08/22/content_ 5315723.htm.

Xi, Jinping. 2019a. Deepening Exchanges and Mutual Learning Among Civilizations For an Asian Community with a Shared Future. China Daily. May 16. https://language.chinadaily.com.cn/a/ 201905/16/WS5cdcb785a3104842260bbe59.html.

Xi, Jinping. 2019b. jianding wenhua zixin, jianshe shehui zhuyi wenhua qiangguo [Strengthening cultural self-confidence and building a strong country with socialist culture]. Qiushi Journal. June 15. http://www.qstheory.cn/dukan/qs/2019-06/15/c_1124626824. htm.

Xin, Ming. 2020. jianchi yi renmin wei zhongxin de lilun zijue [Adhere to the people-centered theoretical consciousness]. People's Daily - Section of Theory. May 22. http://theory.people.com.cn/n1/ 2020/0522/c40531-31718759.html.

Xu, Qiqi. 2017. zhongguo zixin zoujin shijie wutai zhongyang [China confidently approaches the center of the world stage]. Qiushi Journal. November 4. http://www.qstheory.cn/laigao/2017-11/ 14/c_1121955923.htm.

Yang, Jiechi. 2011. China's public diplomacy. Qiushi Journal. July 1. http://english.qstheory.cn/international/201109/t20110924_ 112601.htm.
Yao, Yao. 2018. gonggong waijiao gongzuo ying zhuanhuan xin silu [Public diplomacy should transform new ideas]. In gong gong wai jiao yan jiu (Public Diplomacy Studies), by Debin Liu, 1:4454. Beijing: Social sciences academic press (China).

Yu, Jie. 2017. Opinion: 'strategies' and 'technologies' of Chinese diplomacy after the 19th National Congress. BBC News Chinese, October 18, https://www.bbc.com/zhongwen/simp/chine se-news-41673603.

Yue, Jianyong. 2008. Peaceful rise of China: Myth or reality? International Politics 45 (4): 439-456. https://doi.org/10.1057/ip.2008. 13.

Zhang, Xiaoling, Herman Wasserman, and Winston Mano, eds. 2016. China's media and soft power in Africa: Promotion and perceptions. London: Palgrave. https://doi.org/10.1080/19480881.2017. 1379247.

Zhao, Kejin. 2005. A theoretical clarification on the transition of PRC's diplomatic institutions. Shanghai: Fudan University.

Zhao, Kejin. 2015. The motivation behind China's public diplomacy. The Chinese Journal of International Politics 8 (2): 167-196. https://doi.org/10.1093/cjip/pov005.

Zhao, Kejin. 2019. The China model of public diplomacy and its future. The Hague Journal of Diplomacy 14 (1-2): 169-181. https://doi. org/10.1163/1871191X-14101033.

Zhao, Qizheng. 2012. How China communicates: Public diplomacy in a global age. Beijing: Foreign Language Press.

Zhao, Qizheng, and Weizhen Lei, eds. 2015. Blue book of public diplomacy-Annual report of China's public diplomacy development (2015). Bejing: Social Sciences Academic Press (China).

Zhao, Xinhua. 2013. The critical discourse analysis of Xi Jinping's speech on 'Chinese Dream.' Singapore: National University of Singapore.

Zhou, Enlai. 1989. Selected Works of Zhou Enlai, vol. 2. Beijing: Foreign Languages Press.

Zhou, Qingan, and Qiaoyu Nie. 2019. Identity construction and institutional transition: A new institutional research on China's international communication in 70 years. quanqiu chuanmei xuekan (Global Media Journal) 6 (2): 59-73. https://doi.org/10.16602/j. gmj.20190015.

Zhou, Qingan, and Yue Wu. 2017. Punctuated equilibrium: An institutional history of international communication of China. quanqiu chuanmei xuekan (Global Media Journal) 4 (3): 61-77.

Zi, Zhongyun. 1988. Some characteristics of Post-war U.S. diplomacy. meiguo yanjiu (American Studies) 1: 3-15.

Publisher's Note Springer Nature remains neutral with regard to jurisdictional claims in published maps and institutional affiliations.

Zhao Alexandre Huang is an Associate Professor of Communication at the Université Paris Nanterre (Paris 10). He works at the DICENIDF laboratory. He studies institutional practices, political and public communication strategies, and the formation of strategic narratives in the practice of public diplomacy. His research interests include public diplomacy, strategic communication, public relations, social media, and China's propaganda and international communication. 